\title{
Fiscal Policy and Environment: A Long-Run Multivariate Empirical Analysis of Ecological Footprint in Pakistan.
}

Samia Zahra ( $\sim$ samiazahra022@gmail.com )

GGDC Hangu: Government Girls Degree College Hangu https://orcid.org/0000-0002-8832-053X Dilawar Khan

Kohat University of Science and Technology

Muhammad Nouman

Kohat University of Science and Technology

\section{Research Article}

Keywords: Ecological Footprint, Fiscal Policy, Socio-Economic Determinants, ARDL model, Variance Decomposition Analysis

Posted Date: April 1st, 2021

DOI: https://doi.org/10.21203/rs.3.rs-271216/v1

License: (c) (i) This work is licensed under a Creative Commons Attribution 4.0 International License. Read Full License

Version of Record: A version of this preprint was published at Environmental Science and Pollution Research on August 9th, 2021. See the published version at https://doi.org/10.1007/s11356-021-15665W. 


\title{
FISCAL POLICY AND ENVIRONMENT: A LONG-RUN MULTIVARIATE
} EMPIRICAL ANALYSIS OF ECOLOGICAL FOOTPRINT IN PAKISTAN.

\author{
Samia Zahra1, Dilawar Khan², Muhammad Nouman ${ }^{3}$ \\ ${ }^{1}$ Lecturer in Economics, Higher Education Department, KP \\ ${ }^{2}$ Associate professor at Kohat University of Science and Technology, Kohat. \\ ${ }^{3}$ M.Phil Scholar in Economics, Kohat University of Science and Technology, Kohat.
}

\begin{abstract}
Despite differences in carbon emissions shares and differences in ecological footprint patterns of each nation, these differences are guaranteed to show similar features in long run, thus making it a global issue.
\end{abstract}

An increase in economic growth contributes to an increase in waste production with an impact on environmental degradation and climate change. An ecological footprint is a relatively comprehensive measure than previously used $\mathrm{CO}_{2}$ emission as an environmental proxy as it includes comprehensive multi-facets environmental indicators because ecological footprint includes built-up land, $\mathrm{CO}_{2}$ emission, cropland, fishing ground, grazing land, and forest products which has included all environmental dimensions. This research has focused to empirically investigate the long-run impact of fiscal policy on the ecological footprint in Pakistan keeping different socio-economic factors into consideration. Per annum, time-series data have been collected between 1976 and 2018. The Augmented Dickey-Fuller test has been employed to determine the unit root of the data. To investigate the long-run association between fiscal policy and ecological footprint, modern econometric techniques such as Johansen co-integration test, ARDL Bounds test, different diagnostic tests, and variance decomposition analysis are used. Johnson co-integration test depicts significant long-run co-integration between fiscal policy, ecological footprint, and its major socio-economic determinants in Pakistan. Conclusion of ARDL model shows that $1 \%$ increase in public development expenditures, total population, GDP, and energy consumption increase $0.19,2.17,1.16$, and $2.17 \%$ ecological footprint respectively in Pakistan between 1976 and 2018 and vice versa. However, it is also derived that a 1\% increase in public tax and non-tax revenue and public current expenditures (in health, education, and other 
30 social sectors) shrink 0.36 and $0.013 \%$ ecological footprint in the long-run in Pakistan. The 31 stability, reliability, and credibility of the ARDL model are found correct based on different

32 diagnostic tests. Variance decomposition analysis also depicts fiscal policy significantly cause 33 ecological footprint in Pakistan.

34 Keywords: Ecological Footprint, Fiscal Policy, Socio-Economic Determinants, ARDL model, 35 Variance Decomposition Analysis.

36

37

38

39

40

41

42

43

44

45

46

47

48

49

50

51 


\section{Introduction}

53 Each country has its impact on the environment but anthropogenic emissions are no longer remain

54 domestic but are being transferred through international trade which leads to environmental 55 convergence. This shows that environmental degradation is being transferred between different 56 income groups of the world which validate the existence of environmental convergence. Despite 57 differences in carbon emissions shares and differences in ecological footprint patterns of each nation, these differences are guaranteed to show similar features in long run, thus making it a global issue. In other words, environmental degradation will spread to the equal or same level across the whole world under similar conditions nevertheless of different income groups. (Sarkodie, 2020).

An increase in economic growth contributes to an increase in waste production with an impact on environmental degradation and climate change. The ecological footprint is a relatively comprehensive measure than previously used $\mathrm{CO}_{2}$ emission as an environmental proxy as it includes comprehensive multi-facets environmental indicators because ecological footprint includes built-up land, $\mathrm{CO}_{2}$ emission, cropland, fishing ground, grazing land, and forest products (GFN 2020) which has included all environmental dimensions.

In the current era; ecological footprint is used as one of the important measures of sustainability; exhibits how much bio-capacity is required for human existence and how much is currently available. This measure is used to predict the human burden on the environment which is created every day. It is an important measure because it exhibits to understand the burden of environmental crises by human beings in the struggle to achieve economic sustainability and goals. It is important to consider that many fiscal instruments can be used to achieve environmental cum economic objectives, however, among all of them, taxes and public spending as fiscal policy are the most 75 important fiscal instruments (Postula and Moroz; 2020). Ranging from considering the impact of environmental degradation on living standards; researchers and governments have given special attention to analyzing the correlation between

78 important socio-economic indicators and environmental sustainability. In this regard correlation 79 between environment and economic growth has been explored by John and Pecchenino (1994); 80 Grossman and Krueger (1995); Byrne (1997); Bertinelli et al., 2008, Bostan (2016), Bostan et al., 812010 and Burciu et al., 2010).

82 Similarly, Angelopoulos et al., 2013; Kuo et al., 2016; Vasilev (2019) and Pohoata et al., 2014 
explored the correlation between taxation and environment; Barman and Gupta (2010); Adewuyi (2016); Xie and Wang (2018); Bostan (2015) have explored the relationship between the environmental condition and public or private expenditures.

While Baumol and Oates (1998), Oueslati (2002), Fischer and Heutel (2013), Lopez (2014) Bostan et al., 2016, Bostan et al., 2009 to encounter the process of environmental degradation tried to find out appropriate solutions and environmental policies in the best interest of environmental protection and economic stability. However, the present study considers ecological footprint as a comprehensive measure of environmental degradation.

Taxes, which is one of the vital components of fiscal policy can accelerate proficiency of energy use besides incentives drivers in public taxes which have a positive impact to improve the quality of the environment (Dongyan 2009; Liu et al., 2017 and Balcilar et al. 2016).

Socio-economic indicators taken in this proposed study are important inputs to investigate the nexus between environmental sustainability and economic objectives to be achieved. These socioeconomic inputs are determinants of environmental performance and also indicators of economic growth and development. It is found that is long run while determining the nexus between socioeconomic indicators and environmental inputs (drivers), ecological footprint, share in carbon emissions of nations and ecological performance may differ from its symmetry (equilibrium) but this deviation can be short-term with the trend of returning to equilibrium by applying useful and productive means and policies (Sarkodie, 2020).

Many studies have used $\mathrm{CO}_{2}$ as an environmental degradation indicator, however, there are very limited research studies that have used ecological footprint as an indicator of environmental degradation (Baabou et al., 2017). In this regard to the best of my knowledge, the empirical impact of fiscal policy on ecological footprint as an environmental indicator concerning a developing country like Pakistan has not been explored yet to achieve the ways for sustainable economic development and other joint environmental-economic targets. To evaluate the environmental performance of Pakistan, the empirical methods to determine the impact of fiscal policy keeping important socio-economic indicators in the notice to achieve joint environment targets and economic growth, at least at its minimum level, is the first study to explore. Thus using to explore the impact of fiscal policy on ecological footprint rather than using carbon emissions as an environmental indicator is a more comprehensive approach to access environmental degradation. 
114 The rest part of the study is divided into "Research Methodology" which elaborately explains the 115 research models and methodology, "Results and Discussion" which explains the empirical results 116 of this research study regarding previous research studies, and "Conclusion and Suggestions" 117 which includes some policy implications

\section{Research Methodology}

Discretionary fiscal policy and built-in fiscal stabilizers play an important role to achieve desirable stability of macro-economic variables in different phases of economic fluctuations. To investigate the impact of fiscal policy, economic growth, and energy consumption on the ecological footprint in Pakistan, a time series data has been taken from 1976 to 2018. Total six exogenous variables

123 are examined to explore their impact on ecological footprint, which are further explained in Table 1241 below

125 Table 1: Description of variables.

\begin{tabular}{ll}
\hline Variables & Description \\
\hline EFP & Ecological Footprint in million (gha) \\
\hline TR & $\begin{array}{l}\text { Consolidated Federal and provincial Government tax revenue and non-tax revenue (in } \\
\text { millions of rupees). }\end{array}$ \\
\hline CE & Consolidated federal and provincial government current expenditures (in millions of rupees). \\
\hline DE & Consolidated federal and provincial government development expenditures (in millions of \\
& rupees). \\
\hline TP & The total population in millions \\
\hline EU & Gross Domestic Product in millions (contact 2010 US dollars) \\
\hline
\end{tabular}

127 Both dependent and explanatory variables are converted into the natural log (Martinez- Zarzoso, 128 2011). Log-log model was selected for econometric analysis to determine the elasticity of explanatory variables coefficients. EViews 9 software is used to analyze the research process. 
133 Figure 1 shows the complete research path of this research study to explain the step by step process.

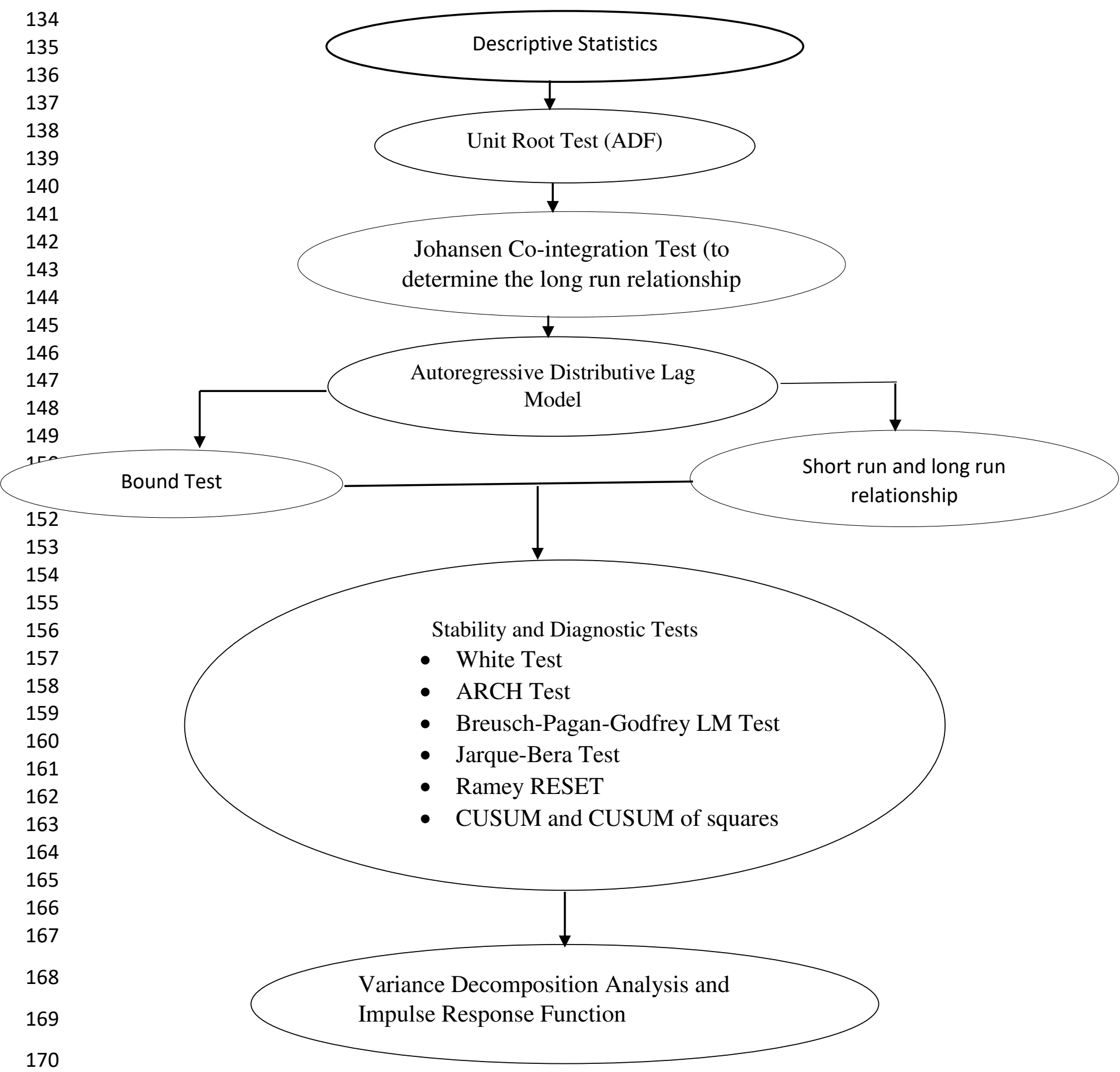

Fig. 1 Flowchart of research methodology.

172 
174 The core objective of this research study is to explore the impact of fiscal policy and other 175 important determinants such as economic growth and energy consumption on the ecological 176 footprint in Pakistan.

177 Functionally,

Fiscal Policy $=f$ (Total Public Revenue, Government Current Expenditures and Public

Development Expenditures).

180

Moreover, the following function is used to determine the associations between ecological footprint and its determinants in Pakistan.

$$
E F P=f(\text { Fiscal Policy }, T P, G D P, E U)=f(T R, C E, D E, T P, G D P, E U)
$$

Where EFP gives the value of ecological footprint, TR gives the value of total public revenue, CE presents the value of current public expenditures in Pakistan, $D E$ represents development expenditure, TP represents total populations in millions between the period of 1976 and 2016, GDP represents economic growth throughout the selected era and EU is a notion used for use of energy in Pakistan. It is important to note that oil used in $\mathrm{KG}$ equivalent per capita is used as a proxy for total energy use in Pakistan.

Log-log model (double log model) is selected for the analysis of this association as it is used to determine the elasticity of coefficients of explanatory variables. In other words, all the data of both dependent and independent variables are converted to a natural logarithm. Mathematically, the following double log model is used to determine the impact of fiscal policy, economic growth, and energy use in Pakistan.

$$
\begin{gathered}
\log E F P_{t}=\beta_{0}+\beta_{1} \log T R_{t}+\beta_{2} \log C E_{t}+\beta_{3} \log D E_{t}+\beta_{4} \log T P_{t}+\beta_{5} \log G D P_{t}+\beta_{6} \log E U_{t}+ \\
e_{t}
\end{gathered}
$$

Where, $B$ shows parameters and $e$ shows residual term at time $t$.

First of all, it is crucial to investigate the problem of the unit root as most of the time-series data are non-stationary. Applying standard OLS regression on non-stationary time series data leads to spurious results. Granger (1969) and Granger and Newbold (1974) called this regression spurious regression. AR (1) autoregressive of order one model is used to determine the condition of stationarity which is given below: 


$$
k_{t}=\theta k_{t-1}+\epsilon_{t}
$$

203 The time-series behavior of $k_{t}$ depends on its previous value $\left(k_{t-1}\right)$ is an axiom of the AR (1) 204 model. There can be three possible instances of this model given below:

205

206

207

208

209

210

211

212

213

214

215

216

217

218

219

220

221

222

223

224

225
If $|\theta|<1$; the series is stationary.

If $|\theta|>1$; the series is explodes.

If $|\theta|=1$; the series is non-stationary.

This study applies the Augmented Dickey-Fuller (ADF) test (Dickey and Fuller 1981) to check the stationarity in this time series data which is an extension of the simple Dickey-Fuller test of a unit root. This test includes the optimal lag length of EFP (dependent Variable) used to eliminate the problem of autocorrelation where Akaike Information Criteria (AIC) is used to determine the optimal lag length. Mathematically the following two equations of the ADF test are utilized in this research paper out of its three equations to deal with the problem of a unit root.

$$
\Delta k_{t}=\beta_{0}+\theta k_{t-1}+\sum_{i=1}^{n} \partial_{i} \Delta k_{t-1}+\epsilon_{t}
$$

$$
\Delta k_{t}=\beta_{0}+\beta_{1} t+\theta k_{t-1}+\sum_{i=1}^{n} \partial_{i} \Delta k_{t-1}+\epsilon_{t}
$$

Intercept term is denoted by $\beta_{0}$ while $\theta$ represents the coefficient of trend variables. On the other hand $\epsilon_{t}$ is used for the error term at time $t$ in the model. For the ADF test, it is hypothesized at the null hypothesis that the data has the problem of the unit root while the alternative hypothesis assumes that the data has not the problem of a unit root.

The second step, after determining the stationarity of data, is to explore the long run possible correlation between ecological footprint and all explanatory variables of this research in Pakistan. Two methods are used to specify the total number of co-integrating vectors or cointegration relationships proposed by Johansen (1988) and Johansen and Juselius (1990). Both of them involve matrix II estimations. The first method is based on Eigen Values with a null hypothesis of co-integration presence in the data up to n co-integration relationships. Otherwise; 
226 the alternative hypothesis for maximum Eigenvalues is about the presence of co-integration but

227 these relationships are more than $n(n+1)$.

228 Mathematically,

$229 T_{\max }(\mathrm{n}+1)=-S \ln \left(1-\partial_{n+1}\right)$

230 The second technique is based on trace statistic used to determine either the number of co-

231 integrating vectors is equal to $\mathrm{n}$ or less than $\mathrm{n}$ and vice versa.

232 Mathematically trace statistic can be presented as follows:

$233 \quad T_{\text {trace }}(\mathrm{n})=-S \sum_{j=n+1}^{r} \ln \left(1-\partial_{n+1}\right)$

234 In both of the above equations, the sample size is denoted by the S sign while $\partial$ shows $i_{t h}$ order 235 projected value while $\mathrm{n}$ manifests a total number of co-integration vectors.

236 As this is the base objective of the research study to explore both the short-run and long-run 237 impact of fiscal policy, use of energy, and economic growth on the ecological footprint in 238 Pakistan, therefore ARDL is the prime adopted econometric model to fulfill this objective. The 239 research study also employs the F bound test (Pesaran et al. 2001) to determine the overall co240 integration in the model. It is important to note that that either all the variables in the model are 241 integrated at $1^{\text {st }}$ difference and vice versa or all of them are mutually co-integrated, ARDL bound 242 test is the best technique to explore the short-run and long-run impact of explanatory variables on 243 the dependent variable in time series data (Janjua et al. 2014).

244 Mathematically, 
$\beta_{3} \log D E_{t-1}+\beta_{4} \log T P_{t-1}+\beta_{5} \log G D P_{t-1}+\beta_{6} \log E U_{t-1}+e_{t}$

248 Equation no 8 shows both long-run and short-run effects with $\alpha_{i}$ and $\beta_{i}$ as short-run and long-run

249 parameters respectively while $\Delta$ shows the differences for stationarity. On the other hand $e_{t}$

250 represents residual term with mean is equal to zero and constant variance. Analytically these

251 short-run and long-run coefficients can be calculated separately in the following mathematical

252 forms (equation no 9 and equation no 10) after determining long-run relationships among

253 variables (Pesaran et al 2001).

254

255

256

257

258

259

260

261

262

263

264

$\Delta \log E F P_{t}=\lambda_{0}+\sum_{i=1}^{m} \lambda_{1 i} \Delta \log T R_{t-k}+\sum_{i=0}^{m_{1}} \lambda_{2 j} \Delta \log C E_{t-k}+\sum_{i=0}^{m_{2}} \lambda_{3 k} \Delta \log D E_{t-k}+$

$\sum_{i=0}^{m_{3}} \lambda_{4 l} \Delta \log T P_{t-k}+\sum_{i=0}^{m_{4}} \lambda_{5 m} \Delta \log G D P_{t-k}+\sum_{i=0}^{m_{5}} \lambda_{6 n} \Delta \log E U_{t-k}+e_{t}$

$$
\log E F P_{t}=\gamma_{0}+\sum_{i=1}^{m} \gamma_{1 i} \log T R_{t-k}+\sum_{i=0}^{m_{1}} \gamma_{2 j} \log C E_{t-k}+\sum_{i=0}^{m_{2}} \gamma_{3 k} \log D E_{t-k}+\sum_{i=0}^{m_{3}} \gamma_{4 l} \log T P_{t-k}+
$$

$\sum_{i=0}^{m_{4}} \gamma_{5 m} \log G D P_{t-k}+\sum_{i=0}^{m_{5}} \gamma_{6 n} \log E U_{t-k}+e_{t}$

It is right important to note that the choice of lag order is receptive to select the optimal lag length for the ARDL model. There are different selection measures used to determine the most suitable lag length. In this study, AIC as a standard measure is used to determine the optimal lag length of the model.

Additionally, six different stability and diagnostic tests are used to determine either the coefficients of the selected ARDL model are reliable, stable, and predictable or not.

The white test included in diagnostic tests is used to determine the problem of heteroscedasticity in the data (White, 1980). To check the residuals autocorrelation and serial correlation ARCH i.e. 
267

268

269

270

271

272

273

274

275

276

277

278 279 variable.

Autoregressive Conditional Heteroscedasticity (Engle, 1982) and Breusche - Pagan - Godfrey

LM test (Breusch, 1978; Godfrey, 1978) are used respectively. Similarly, Jarque - Bera test (Jarque and Bera, 1987) and the Ramsey RESET test (Ramsey, 1969) are employed to check the normal distribution of the residual terms and specification of the model i.e. appropriate selection of the model are used respectively. In addition to them, CUSUM (cumulative sum of residuals) and CUSUMQ (cumulative sum of the square of residuals) are used to check the stability of ARDL parameters (Brown et al. 1975).

Lastly, this research methodology uses variance decomposition analysis and impulse response functions that are generated from the Cholesky technique. The variations in any independent variable into the component fluctuations or shocks within the vector autoregressive is split by variance decomposition. In another word, these techniques determine the forecast of error variance of each of the variables; which can be clarified by exogenous shocks to the dependent

\section{Empirical Results and Description}

Time-series data is utilized to determine the impact of fiscal policies, economic growth, and energy consumption for the period of 1976 to 2018 in Pakistan. The data is collected from different resources such as data of World Bank, Pakistan Bureau of Statistics, 50 Years of Yearly Statistic Book of Pakistan since 1976, and Global Footprint Network. It is evident from Table 2, which interprets the description of all variables included in this research model, that descriptive statistics are vital to understanding the overall features of the data. It also helps in comprehending the basic features and trends of the ecological footprint and all other explanatory variables of the model. The mean value of the dependent variable is 104.08 in million (gha) ranging from 43.62 in million (gha) to 169.87 in million (gha) with a standard deviation of 39.65 used to measure dispersion in the data. Similarly, average values of consolidated Federal and Provincial Government tax and non-tax revenue (in millions of rupees), aggregate Federal and Provincial Government current 
292 expenditures (in millions of rupees), public development expenditures (in millions of rupees), the 293 total population in millions, Gross Domestic Product at constant 2010 US \$ and use of energy (oil 294 in $\mathrm{kg}$ ) are 782715.7, 961703.1, 215403.5, 134.58, 118183.7 and 420.69 with standard deviation (a 295 measure of dispersion) 39.65, 889756.9, 889756.9, 1160676, 246985.3, 44.10, 63897.42 and 29666.24 respectively.

297 Table2: Descriptive statistics.

\begin{tabular}{|c|c|c|c|c|c|c|c|}
\hline Variables & EFP & TR & $\mathrm{CE}$ & DE & TP & GDP & $\mathbf{E U}$ \\
\hline \multicolumn{8}{|l|}{ Mean } \\
\hline & 104.0854 & 782715.7 & 961703.1 & 215403.5 & 134.58 & 118183.7 & 420.69 \\
\hline \multicolumn{8}{|l|}{ Median } \\
\hline & 104.0348 & 368260.0 & 423866.0 & 90106.00 & 131.06 & 105342.8 & 440.25 \\
\hline \multicolumn{8}{|l|}{ Max. } \\
\hline & 169.8562 & 2694300.0 & 3605100. & 775600.0 & 216.57 & 256728.8 & 527.43 \\
\hline \multicolumn{8}{|l|}{ Min. } \\
\hline & 43.62359 & 19264.00 & 19963.00 & 12366.00 & 68.83 & 33583.02 & 299.10 \\
\hline S.D. & 3965019 & 8897569 & 1160676 & 2469853 & 44.10 & 63897.42 & 66.24 \\
\hline
\end{tabular}

298

Source: Author(s) calculations.

299 Additionally, Figure 2 represents the periodic trends of ecological footprint and all explanatory 300 variables of the model in Pakistan. It is determined that current expenditures, public development 301 expenditures, and public revenue has upward fluctuation trends while total population and GDP 302 have been increased over a selected period. It is also shown that the use of energy and ecological 303 footprint has overall increasing trends with the same patterns approximately. 

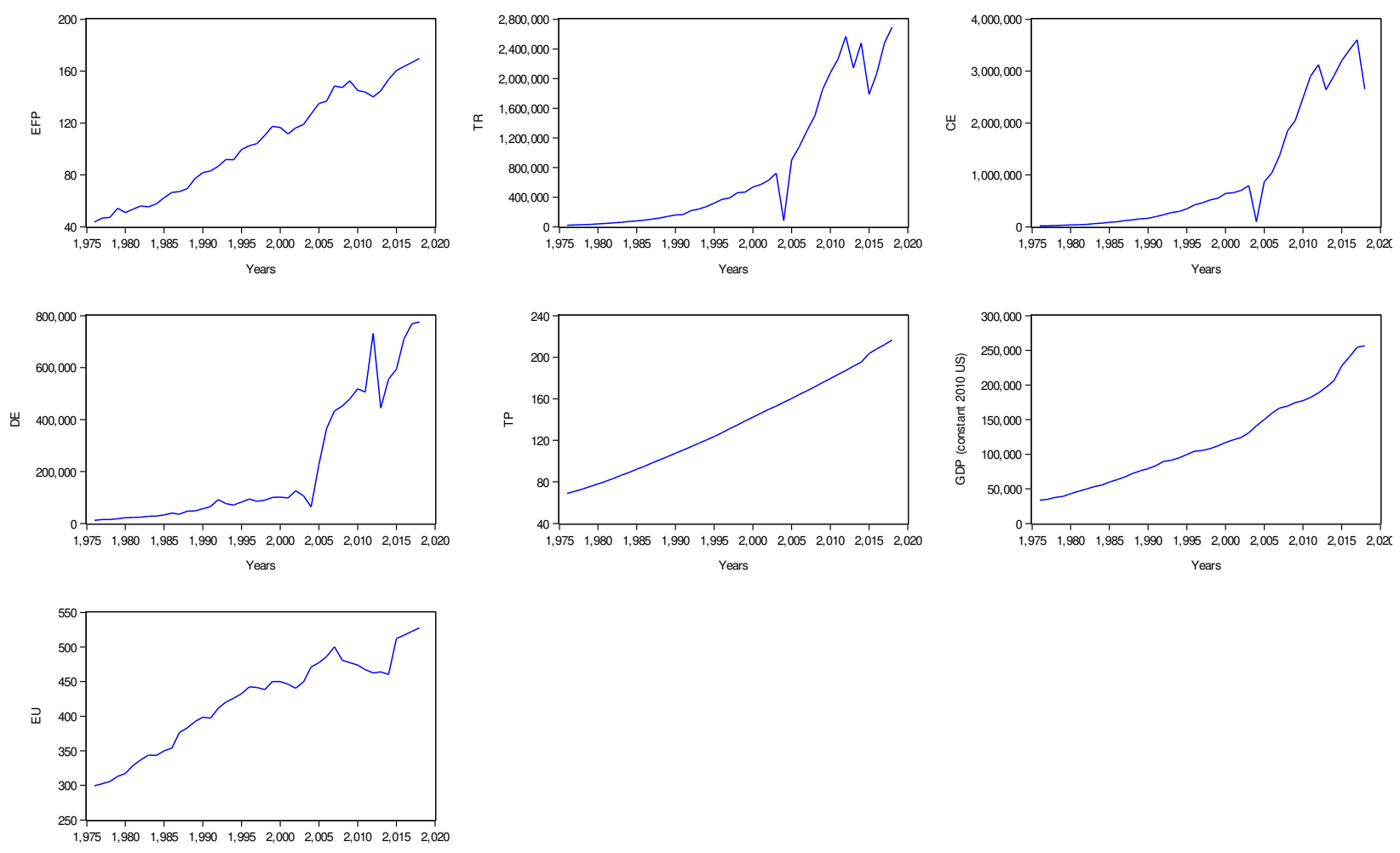

Years

Figure 2: Periodic trends of ecological footprint and explanatory variables in Pakistan.

The first step towards the econometric analysis of this research study is to analyze the data for

307 stationarity. The problem of unit root usually arises due to the presence of time trends in time series data. Employing regression analysis with unit root trends in the data gives the results of spurious regression and parameter estimation in such situations determines misleading and unpredictable results (Granger and Newbold, 1974). Therefore; at first instance, the data is analyzed to determine the stationarity of the data by retaining the Augmented Dickey-Fuller test at constant trend (Dickey and Fuller, 1981) shown in Table 3. 
Table 3: Results of ADF test (constant).

\begin{tabular}{|c|c|c|c|c|c|}
\hline Variables & Test equation & $t$ stat. & $P$-value & Lags & Conclusion \\
\hline LogEFP & & -1.79 & 0.38 & (1) & \\
\hline$\Delta \operatorname{LogEFP}$ & Constant & $-4.33^{*}$ & $<0.05$ & (1) & $\mathrm{I}(1)$ \\
\hline $\log T R$ & & -1.02 & 0.74 & (1) & \\
\hline$\Delta \log T R$ & Constant & $-6.84 *$ & $<0.05$ & (1) & $\mathrm{I}(1)$ \\
\hline $\log C E$ & & -1.03 & 0.73 & (1) & \\
\hline$\Delta \log C E$ & Constant & $-6.40^{*}$ & $<0.05$ & (1) & $\mathrm{I}(1)$ \\
\hline $\log \mathrm{DE}$ & & -0.51 & 0.88 & (1) & \\
\hline$\Delta \log \mathrm{DE}$ & Constant & $-5.58 *$ & $<0.05$ & (1) & $\mathrm{I}(1)$ \\
\hline $\log T P$ & & -4.84 & 0.75 & (1) & \\
\hline$\Delta \log T \mathrm{P}$ & Constant & -3.84 & $<0.05$ & (1) & $\mathrm{I}(1)$ \\
\hline LogGDP & & -2.94 & 0.20 & (1) & \\
\hline$\Delta$ LogGDP & Constant & -4.84 & $<0.05$ & (1) & $\mathrm{I}(1)$ \\
\hline $\operatorname{LogEU}$ & & -2.57 & 0.109 & (1) & \\
\hline$\Delta \mathrm{LogEU}$ & Constant & $-3.094 *$ & $<0.05$ & (1) & $\mathrm{I}(1)$ \\
\hline
\end{tabular}

*5\% level of significance. Source: Author(s) calculations.

318 These results show that each one of the series has the problem of unit root at level but become 319 stationarity at the first difference at 5\% level of significance. In other words, all the variables in 320 this research study for a period of 1976 to 2018 have the first order of integration I (1) series at 3210.05 level.

322 According to Engle and Granger (1987) when all the series of data is integrated at the same order 323 of integration, then Johansen co-integration test $(1988,1991)$ is an appropriate tool to determine 324 the variable movement of data in the long run. Keeping the results of the stationarity test in mind, 325 Johansen co-integration test is a good selected test at the next step to determine the long-run 326 relationship between dependent and independent variables of this research model.

327 Table 4: Outcome of Johanson Co-integration

$\begin{array}{ccccccc}\boldsymbol{H}_{\mathbf{0}} & \boldsymbol{H}_{\mathbf{1}} & \text { Eigen Value } & \text { Trace Value } & \text { C.V 5\% } & \text { P Values** } & \begin{array}{c}\text { Co-integrating } \\ \text { Equations }\end{array} \\ & & & & & & \text { None * } \\ \boldsymbol{H}_{\mathbf{0}}: \boldsymbol{j}=\mathbf{0} & H_{1}: j=1 & 0.74 & 175.00 & 125.61 & 0.00 & \text { At most } 1 * \\ \boldsymbol{H}_{\mathbf{0}}: \boldsymbol{j} \leq \mathbf{1} & H_{1}: j=2 & 0.654 & 125.06 & 95.75 & 0.00 & \text { At most } 2 * \\ \boldsymbol{H}_{\mathbf{0}}: \boldsymbol{j} \leq \mathbf{2} & H_{1}: j=3 & 0.58 & 85.76 & 69.82 & 0.00 & \text { At most } 3 * \\ \boldsymbol{H}_{\mathbf{0}}: \boldsymbol{j} \leq \mathbf{3} & H_{1}: j=4 & 0.45 & 53.24 & 47.86 & 0.01 & \end{array}$




$\begin{array}{ccccccc}\boldsymbol{H}_{\mathbf{0}}: \boldsymbol{j} \leq \mathbf{4} & H_{1}: j=5 & 0.36 & 31.28 & 29.80 & 0.03 & \text { At most } 4 * \\ \boldsymbol{H}_{\mathbf{0}}: \boldsymbol{j} \leq \mathbf{5} & H_{1}: j=6 & 0.26 & 14.93 & 15.49 & 0.06 & \text { At most } 5 \\ \boldsymbol{H}_{\mathbf{0}}: \boldsymbol{j} \leq \mathbf{6} & H_{1}: j=7 & 0.10 & 3.96 & 3.84 & 0.04 & \text { At most } 6 * \\ \text { Max- Eigen Statistic } & & & & & \text { None } * \\ \boldsymbol{H}_{\mathbf{0}}: \boldsymbol{j}=\mathbf{0} & H_{1}: j=1 & 0.74 & 49.94 & 46.23 & 0.01 & \text { At most } 1 * \\ \boldsymbol{H}_{\mathbf{0}}: \boldsymbol{j} \leq \mathbf{1} & H_{1}: j=2 & 0.65 & 39.30 & 40.08 & 0.06 & \text { At most } 2 * \\ \boldsymbol{H}_{\mathbf{0}}: \boldsymbol{j} \leq \mathbf{2} & H_{1}: j=3 & 0.58 & 32.53 & 33.89 & 0.072 & \text { At most } 3 * \\ \boldsymbol{H}_{\mathbf{0}}: \boldsymbol{j} \leq \mathbf{3} & H_{1}: j=4 & 0.45 & 21.96 & 27.58 & 0.22 & \text { At most } 4 * \\ \boldsymbol{H}_{\mathbf{0}}: \boldsymbol{j} \leq \mathbf{4} & H_{1}: j=5 & 0.36 & 16.35 & 21.13 & 0.21 & \text { At most } 5 \\ \boldsymbol{H}_{\mathbf{0}}: \boldsymbol{j} \leq \mathbf{5} & H_{1}: j=6 & 0.26 & 10.97 & 14.26 & 0.16 & \text { At most } 6 * \\ \boldsymbol{H}_{\mathbf{0}}: \boldsymbol{j} \leq \mathbf{6} & H_{1}: j=7 & 0.10 & 3.96 & 3.84 & 0.05 & \text {. }\end{array}$

C.V presents critical values. Statistical significance: $* 5 \%$ level of significance

Table 4 reveals the outcomes of the Johansen co-integration test with seven co-integrated vectors at a 5\% level of significance along with trace and max Eigenvalue. In both Trace and Max-Eigen value statistics null hypotheses of $H_{0}: \mathrm{j}=0, H_{0}: \mathrm{j} \leq 1, H_{0}: \mathrm{j} \leq 2, H_{0}: \mathrm{j} \leq 3, H_{0}: \mathrm{j} \leq 4, H_{0}: \mathrm{j} \leq 5, H_{0}: \mathrm{j} \leq 6$ are tested against alternative hypotheses of $H_{1}: \mathrm{j}=0, H_{1}: \mathrm{j}=1, H_{1}: \mathrm{j}=2, H_{1}: \mathrm{j}=3, H_{1}: \mathrm{j}=4, H_{1}: \mathrm{j}=5, H_{1}$ : $\mathrm{j}=6, H_{1}: \mathrm{j}=7$.

Results show that in the case of the Trace test there are six co-integration vectors at 0.05 level which determine the rejection of their null hypotheses against alternative hypotheses. On the other hand, the Max-Eigenvalue tool determines one co-integration vector at a 5\% level of significance. It is important to note when there is controversy in deciding the number of co-integration vectors between Trace Test and Max- Eigenvalue in the model, the most appropriate test is the Trace test to decide the appropriateness of co-integration vectors (Johansen and Juselius, 1990).

341 It is concluded that both exogenous and endogenous variables are jointly co-integrated to each 342 other; determining the long-run relationship between a dependent variable that is ecological 343 footprint and fiscal policy besides energy consumption.

344 The research satisfies the condition to use ARDL Bound test developed by Pesaran et al. (2001) 345 and that is all the variables in the selected model are stationary at first difference. F Bound test is 346 used to explore the overall co-integration of the model contrary to giving a picture about co347 integration of individual variables. 
Table 5: Results of ARDL F-Bound test.

\begin{tabular}{|l|l|c|}
\hline & \multicolumn{1}{|c|}{ F-Bound Test } & \\
\hline F-statistic & $* 6.66$ & \\
\hline $\mathrm{K}$ & 6 & $\mathbf{L}$ \\
\hline Significance level & Lo $_{\mathbf{1}}$ (lower bound critical value) & 3.23 \\
\hline $10 \%$ & 2.12 & 3.61 \\
\hline $5 \%$ & 2.45 & 3.99 \\
\hline $2.5 \%$ & 2.75 & 4.43 \\
\hline $1 \%$ & 3.15 & upper bound critical value) \\
\hline
\end{tabular}

$* 1 \%$ level of significance. Source: Author(s) calculations.

352 As shown in Table 5, 6.66 (F statistic) is greater than the upper critical bound at 0.05 level of significance, suggesting the presence of long-run co-integration between explanatory variables and ecological footprint in Pakistan.

After determining the overall long-run relationship between the dependent variable and explanatory variables; the analysis is advanced to find out short-run and long-run elasticities by the ARDL model shown in Table 6. More elaborately the result ARDL model also determines the positive or negative relationship between the dependent and explanatory variables in both the short-run and long run. Additionally, it also determines the significance of all explanatory variables to decide either each of them is determinant of ecological footprint in the short and long period. 
Table6: Results of ARDL model.

\begin{tabular}{|c|c|c|c|c|}
\hline Variables & Short-run elasticity & Std. error & t-statistic & prob. \\
\hline$\Delta \log E F P_{t-1}$ & 0.89 & 0.26 & 3.40 & 0.006 \\
\hline$\Delta \log T R_{t}$ & -0.05 & 0.12 & -0.46 & 0.65 \\
\hline$\triangle \log C E_{t}$ & 0.089 & 0.07 & 1.27 & 0.22 \\
\hline$\Delta \log D E_{t}$ & 0.0079 & 0.05 & 0.15 & 0.88 \\
\hline$\Delta \log T P_{t}$ & 10.73 & 7.93 & 1.35 & 0.20 \\
\hline$\Delta \log G D P_{t}$ & 0.28 & 0.50 & 0.56 & 0.59 \\
\hline$\overline{\Delta l o g E U_{t}}$ & 0.79 & 0.50 & 1.56 & 0.14 \\
\hline \multirow[t]{2}{*}{$E C T_{t-1}$} & -1.95 & 0.39 & -5.05 & $\leq 0.05$ \\
\hline & Long run elasticity & & & \\
\hline $\log T R_{t}$ & -0.36 & 0.18 & -2.00 & 0.07 \\
\hline $\log C E_{t}$ & -0.013 & 0.05 & -0.26 & 0.79 \\
\hline $\log D E_{t}$ & 0.19 & 0.04 & 4.58 & $\leq 0.05$ \\
\hline $\log T P_{t}$ & 2.17 & 0.32 & 6.86 & $\leq 0.05$ \\
\hline $\log G D P_{t}$ & 1.16 & 0.18 & 6.32 & $\leq 0.05$ \\
\hline $\log E U_{t}$ & 2.17 & 0.22 & 9.71 & $\leq 0.05$ \\
\hline Constant & -2.59 & 0.48 & -5.39 & $\leq 0.05$ \\
\hline
\end{tabular}

373 Table 6 shows the negative association of consolidated tax and non-tax public revenue to the

374 ecological footprint in Pakistan. In other words, a $1 \%$ increase in public revenue reduces $0.05 \%$ 375 ecological footprint in Pakistan.

376 Contrary, an increase in public expenditures, total population, and energy consumption lead to an 377 increase in ecological footprint in the selected period in Pakistan in the short run. Moreover, in

378 the short run, a 1\% increase in public current expenditures, public development expenditures, 379 total population, and energy consumption lead to a $0.089 \%, 0.0079 \%, 10.73 \%$, and $0.79 \%$ 380 increase in ecological footprint in Pakistan. 
381 Similarly, in the short-run there is a positive and significant relationship of economic growth is noted with an ecological footprint in Pakistan. It is interesting to note that a $1 \%$ increase in GDP in Pakistan leads to a $0.28 \%$ increase in ecological footprint.

384 On the other hand, a long-run negative association is observed between total public revenue and 385 ecological footprint and current public expenditures and ecological footprint in Pakistan likewise 386 in the short run. It is depicted from the results that a $1 \%$ increase in both these variables leads to a $0.36 \%$ and $0.013 \%$ decrease in ecological footprint in long run. Similar to these results taxes are interpreted as one of the important built-in stabilizers and instruments of fiscal policy that escalate energy efficiency along with a positive but significant influence on the quality of the environment (Dongyan 2009; Liu et al., 2017 and Balcilar et al., 2016).

It is important to note that all the explanatory variables in the short-run are insignificant, determining that all selected independent variables are not the major determinants of ecological footprint at a 5\% level of significance in Pakistan between 1976 and 2018.

394 Alternatively, in the long-run total public revenue and public current expenditures are insignificant at a 0.05 significance level depicting these two variables are not the major cause of ecological footprint. However, both of these variables are negatively associated with an ecological footprint in Pakistan in long run. It is important to note that a $1 \%$ increase in current public expenditures and public revenue causes a $0.013 \%$ and $0.36 \%$ reduction in ecological footprint in Pakistan respectively in long run. Concerning the results of this paper, it is quoted that taxes, which is one of the vital components of fiscal policy can accelerate proficiency of energy use besides incentives drivers in public taxes which have a positive impact to improve the quality of the environment (Dongyan 2009; Liu et al., 2017 and Balcilar et al., 2016). As is

403 shown in table 6 that there is a negative relationship between current public expenditures and 404 ecological footprint in long run. The same results have been explored by noting that shares of 405 public expenditures in sectors of education and health (a portion of current public expenditures) 406 accelerate the level of present and prospective future income, lead to improving environmental 
quality which is a major income effect in the environmental arena. Besides, public consumption may lead to stabilizing institutions which is also a cause of environmental quality enhancement. Therefore, it is concluded that government expenditures are a significant but positive determinant of environmental quality (Lopez et al., 2011). In support of these conclusions, it is cited that government expenditures both in direct and indirect spheres minimize sulfur emissions besides the inconclusive results are noted for both direct and indirect shares of public expenditures in case of $\mathrm{CO}_{2}$ emission (Halkos and Paizanos, 2013). Adewuyi (2016) noted negative but direct and indirect relationship among public expenditures and $\mathrm{CO}_{2}$ emissions. Additionally, Katircioglu and Katircioglu (2018) noted the same negative but significant relationship between public spending and carbon emission in long run in the case of Turkey.

In long run, development expenditures, energy consumption, GDP, and the total population of Pakistan have positive dominancy and are major determinants of the ecological footprint from 1976 to 2018. McAusland (2008) agreed to these results by exploring that there are different procedures involved as fiscal policy determinants that may negatively influence environmental standards. Fiscal expenditures negatively affect the quality and standards of the environment by differentiating the real causes of environmental degradation in form of either consumption or production produced. Similarly, in the context of China, Yuelan et al. (2019) empirically explored the positive and significant relationship between environmental degradation and fiscal policy tools (particularly expansionary fiscal policy tools). A positive and significant impact of public expenditure in both consumption $\mathrm{CO}_{2}$ emission and production $\mathrm{CO}_{2}$ has been explored (Muhafidin, 2020). 1\% increase in development expenditures, energy consumption, GDP, and the total population in long run becomes the major cause of $0.19 \%, 2.17 \%, 1.16 \%$, and $2.17 \%$ increase in ecological footprint in Pakistan in long run. Similarly, Muhafidin (2019) explored the positive relationship between population and environmental degradation in Indonesia. According to him because of the expansion in population, there is an increase in consumption patterns as well, which may cause an increase in the use of energy, leads to intensifying greenhouse gas 
433 emitters. Regarding the relationship between energy consumption and the ecological footprint of

434 this research study, the same results are explored by noting an increase in the use of different

435 sources of energy like oil and natural gas plays an essential role as a key determinant of air

436 pollution (Kristom, 2003). Similarly, Alper and Oguz (2016) have also investigated the positive

437 relationship between environmental degradation and the use of energy sources and

438 industrialization. It is explored that practically a strong positive relationship is expected between

439 energy consumption and economic growth. An increase in the use of energy leads to accelerate

440 pace of economic growth which is a major cause of environmental degradation (Alvarado and

441 Toledo, 2016). Energy consumption is one of the important determinants of environmental

442 pollution in the context of the Environmental Kuznets Curve. In most the studies noticeable

443 harmful impact of energy consumption on environmental pollution is found (Haq et al., 2019;

444 Gamage et al., 2017; Jalil et al., 2009; Shahbaz et al., 2014; Hossain, 2012; Ozturk and Mulali,

445 2015). Similarly, economic activity is considered as an important determinant of environmental

446 quality degradation which leads to an increase in income level at expenses of natural resources

447 exploitation, thus cause environmental pollution. (Guo et al., 2019). In the environmental

448 economics literature, the relationship or association between economic growth and

449 environmental degradation is studied as an important sphere of the Environmental Kuznets

450 Curve i.e. (Narayan and Narayan, 2010; Apergis and Payne, 2010; Fodha and Zaghdoud, 2010).

451 It is also revealed that all the variables are less elastic except total population in short-run

452 interpret that elasticity's values are less than 1 while other factors are remaining constant. On the

453 other hand; the case is different in the long run where public revenue, public current

454 expenditures, and development expenditures are inelastic while total population, economic 
455 growth, and energy consumption are more elastic in Pakistan for selected period with the

456 condition of other determinant held constant.

457 To check the stability of the ARDL model in long run, ECT is introduced as co-integration Eq (458 1) which is significant at a 5\% level with a negative sign. This turn-out explains that the ARDL 459 model dynamically stable in long run. This result show that $195 \%$ more imbalance 460 appropriateness would bring ARDL long-run stability.

461 Fiscal instruments are significant determinants in the USA (Halkos and Paizanos ; 2016) while 462 Yeulan et al. (2019) explored the same conclusion for China which is to some extend is exact to 463 the existing results of this research paper. Similarly, many studies have explored the symmetric 464 impact of fiscal policies on environmental quality (Lepoz et al., 2011; Katircioglu and 465 Katircioglu 2018; Chan 2020; Halkos and Paizanos 2016 and Yuelan et al., 2019)

466 Above all, the best 20 ARDL models are given in Table 7. There are five different types of 467 model selection criteria which are log-likelihood, SBC, HQ, AIC, and adjusted $R^{2}$.

468 Table 7: ARDL model specification

\begin{tabular}{|c|c|c|c|c|c|c|}
\hline Model & $\log L$ & AIC* & BIC & HQ & Adj. $R^{2}$ & Specification \\
\hline 1 & 134.70 & -6.09 & -4.99 & -5.71 & 0.99 & $\operatorname{ARDL}(1,0,0,0,0,0,0$ \\
\hline 2 & 133.58 & -6.08 & -5.03 & -5.72 & 0.99 & $\operatorname{ARDL}(3,3,3,3,0,2,3)$ \\
\hline 3 & 132.99 & -6.05 & -4.99 & -5.69 & 0.99 & $\operatorname{ARDL}(2,3,3,3,1,2,3)$ \\
\hline 4 & 134.73 & -6.04 & -4.90 & -5.64 & 0.99 & $\operatorname{ARDL}(3,3,3,3,1,3,3$ \\
\hline 5 & 134.72 & -6.04 & -4.90 & -5.64 & 0.99 & $\operatorname{ARDL}(3,3,3,3,2,2,3$ \\
\hline 6 & 133.69 & -6.04 & -4.94 & -5.65 & 0.99 & $\operatorname{ARDL}(3,3,3,3,0,3,3)$ \\
\hline 7 & 132.47 & -6.03 & -4.97 & -5.66 & 0.99 & $\operatorname{ARDL}(2,3,3,2,1,3,3$ \\
\hline 8 & 133.46 & -6.03 & -4.93 & -5.64 & 0.99 & $\operatorname{ARDL}(2,3,3,3,1,3,3)$ \\
\hline 9 & 135.31 & -6.02 & -4.83 & -5.60 & 0.99 & $\operatorname{ARDL}(3,3,3,3,3,2,3)$ \\
\hline 10 & 132.99 & -5.99 & -4.90 & -5.62 & 0.99 & $\operatorname{ARDL}(2,3,3,3,2,2,3$ \\
\hline 11 & 131.91 & -5.60 & -4.94 & -5.63 & 0.99 & $\operatorname{ARDL}(3,3,3,2,1,2,3)$ \\
\hline 12 & 133.85 & -5.99 & -4.85 & -5.60 & 0.99 & $\operatorname{ARDL}(2,3,3,3,3,2,3)$ \\
\hline 13 & 132.76 & -5.98 & -4.89 & -5.60 & 0.99 & $\operatorname{ARDL}(3,3,3,2,1,3,3)$ \\
\hline 14 & 134.74 & -5.98 & -4.80 & -5.58 & 0.99 & $\operatorname{ARDL}(3,3,3,3,2,3,3)$ \\
\hline 15 & 130.69 & -5.98 & -4.97 & -5.63 & 0.99 & $\operatorname{ARDL}(3,3,3,2,0,2,3)$ \\
\hline 16 & 130.61 & -5.98 & -4.97 & -5.63 & 0.99 & $\operatorname{ARDL}(2,3,3,2,1,2,3)$ \\
\hline 17 & 133.49 & -5.97 & -4.83 & -5.57 & 0.99 & $\operatorname{ARDL}(2,3,3,3,2,3,3)$ \\
\hline 18 & 132.47 & -5.97 & -4.87 & -5.58 & 0.99 & $\operatorname{ARDL}(2,3,3,2,2,3,3$ \\
\hline 19 & 135.34 & -5.96 & -4.73 & -5.53 & 0.99 & $\operatorname{ARDL}(3,3,3,3,3,3,3)$ \\
\hline 20 & 131.32 & -5.96 & -4.91 & -5.59 & 0.99 & $\operatorname{ARDL}(3,3,3,2,0,3,3)$ \\
\hline
\end{tabular}

469 Source: Author(s) calculations. 
475

Table8: Results of diagnostic tests.

\begin{tabular}{llccc}
\hline Test type & Statistic & Value & d.f & Prob. \\
\hline White test & $\chi^{2}$ statistic & 26.78 & $d f(24)$ & 0.31 \\
\hline ARCH test & $\chi^{2}$-tatistic & 2.29 & $d f(1)$ & 0.13 \\
\hline Breusch-Pagan-Godfrey LM test & $\chi^{2}$-tatistic & 27.35 & $d f(13)$ & 0.29 \\
\hline Jarque-Bera test & F-statistic & 0.96 & - & 0.61 \\
\hline Ramsey RESET test & F-statistic & 0.006 & $d f(1,10)$ & 0.94
\end{tabular}

Source: Author(s) calculations.

477

$\mathrm{ARCH}$ and LM tests suggest that there is no evidence of heteroscedasticity and serial correlation in the model. Similarly, the Ramsey RESET test (Ramsey 1969) elaborates that the ARDL model is the best-selected model for the selected research problem. Jarque Bera's (1987) test shows that the ARDL model is normally distributed. The results are based on the probability values of the respective tests as all the probability values of diagnostic are more than 0.05 .

482

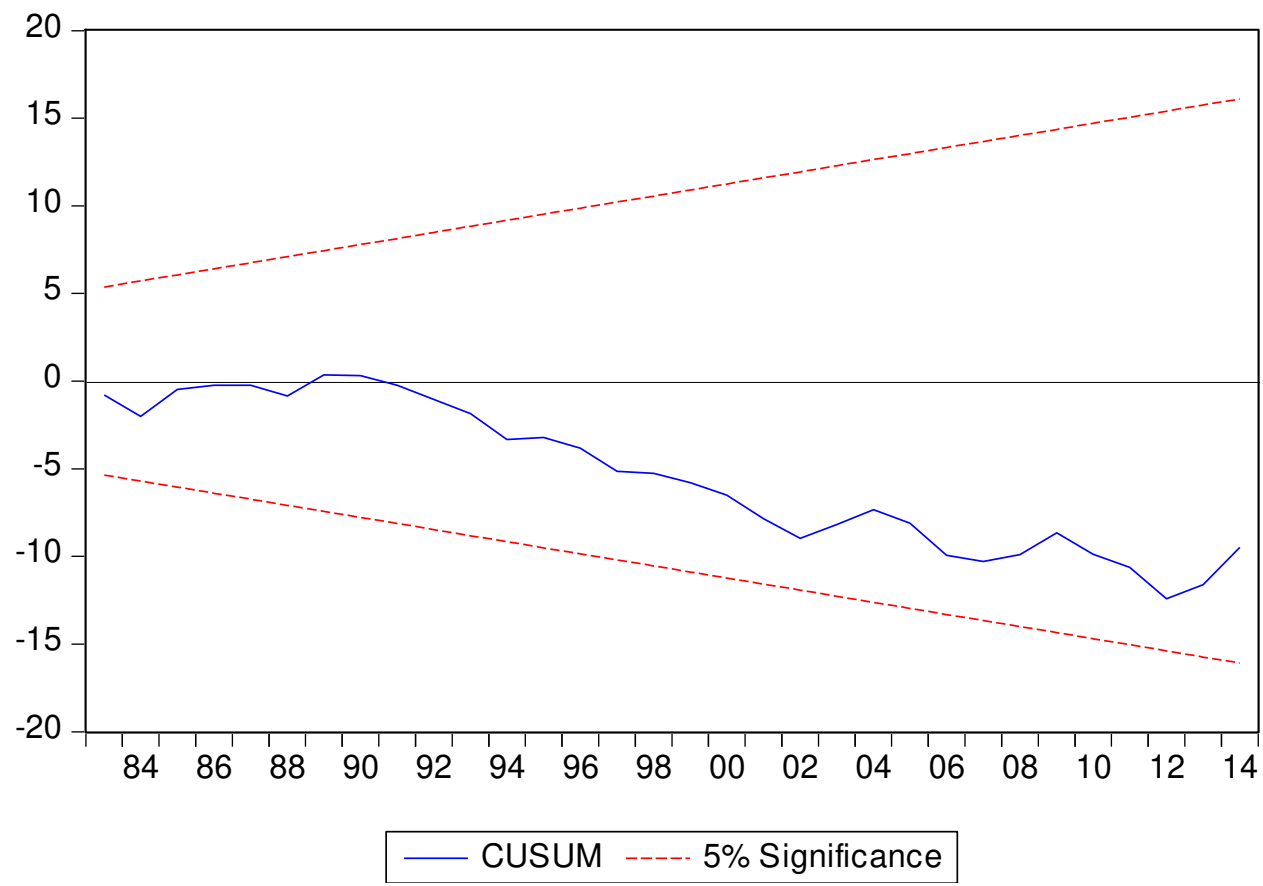

Fig 3: Results of CUSUM test.

However, in this study, AIC criteria is used to select the best fitted Autoregressive Distributive Lag model. Given in Table 7 the best fitted model is ARDL $(1,0,0,0,0,0,0)$ selected on the basis of smallest AIC value (-6.09).

To confirm the credibility and correctness of the ARDL model; different diagnostic tests are employed and the results are given in Table 8. 

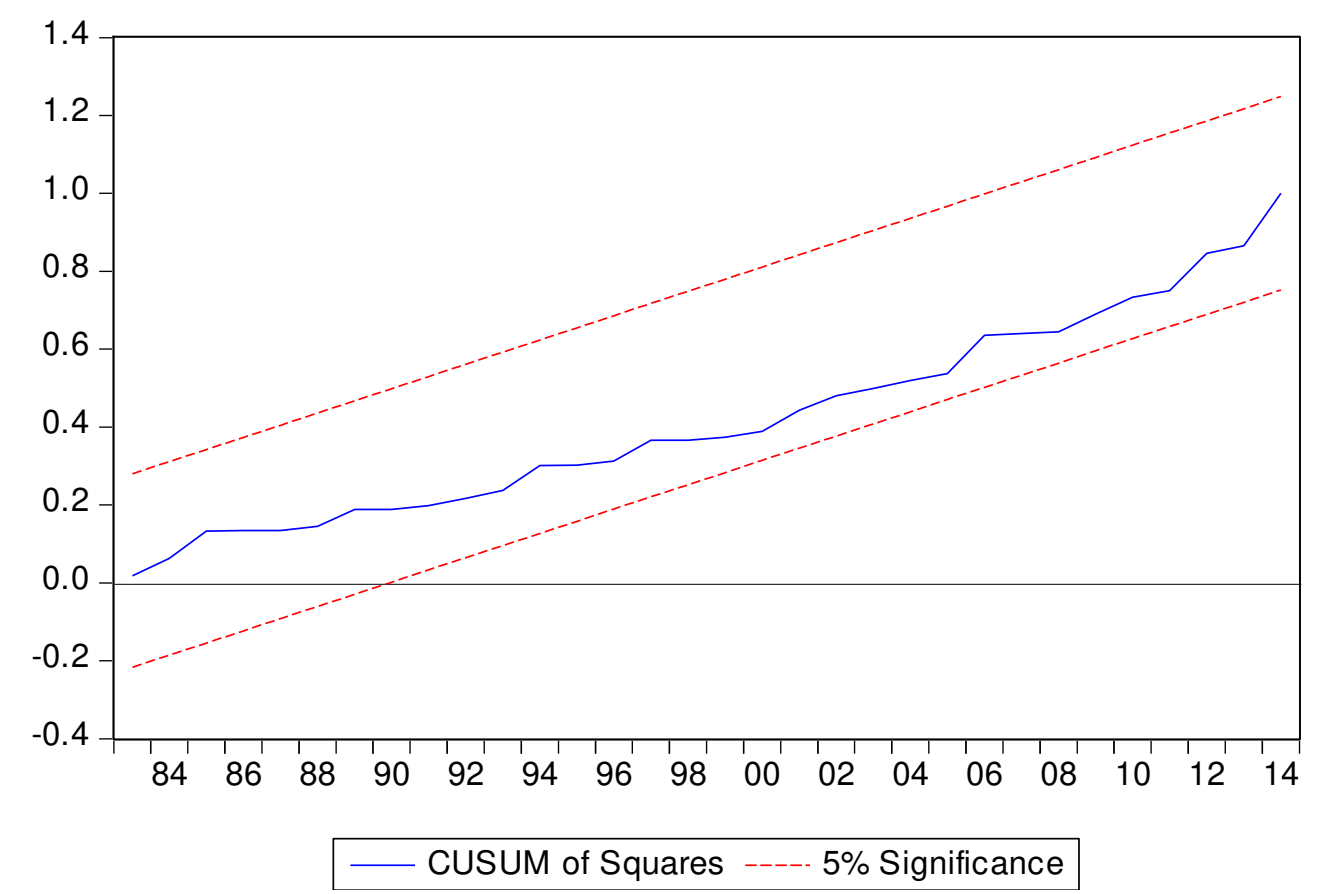

Fig 4: Results CUSUMSQ tests.

488 Figure 3 and Figure 4 show that CUSUM and CUSUMSQ tests are stable because their respective 489 lines are within the boundaries at a 5\% level of significance. These findings indicate that the ARDL 490 model is stable and reliable in the current condition.

491 Table 9 shows the results of Variance and Decomposition Analysis of all explanatory variables of 492 the model in combination with ecological footprint for the total horizon of periods.

493 Table 9: Results of Variance Decomposition Analysis

\begin{tabular}{lccccccccc}
\hline Periods & SE & EFP & TR & CE & DE & TP & GDP & EU \\
\hline 1 & 0.015 & 100.0 & 0.00 & 0.0 & 0.00 & 0.00 & 0.00 & 0.00 \\
2 & 0.018 & 78.72 & 4.57 & 2.97 & 0.27 & 0.95 & 12.51 & 0.005 \\
3 & 0.019 & 67.10 & 3.93 & 2.82 & 0.38 & 1.38 & 13.63 & 10.75 \\
4 & 0.02 & 58.74 & 3.49 & 5.90 & 3.25 & 2.46 & 15.51 & 10.64 \\
5 & 0.023 & 49.80 & 3.59 & 6.41 & 10.93 & 3.56 & 16.62 & 9.09 \\
6 & 0.025 & 43.65 & 3.22 & 6.15 & 17.08 & 4.11 & 17.83 & 7.96 \\
7 & 0.026 & 40.74 & 3.65 & 5.61 & 21.03 & 4.03 & 17.44 & 7.49 \\
8 & 0.026 & 39.19 & 4.24 & 5.35 & 23.43 & 3.81 & 16.79 & 7.18 \\
9 & 0.027 & 38.09 & 4.57 & 5.28 & 24.74 & 3.81 & 16.55 & 6.95 \\
10 & 0.027 & 37.45 & 4.87 & 5.22 & 24.98 & 4.08 & & 16.56 & 6.83 \\
\hline
\end{tabular}

Source: Author's computation

495 The results of this test show that fluctuations in ecological footprint are triggered by shocks of its 496 own as well as impulses in all other factors. It is evident that 4.87, 5.22, 24.98, 4.08, 16.56, and 
$6.83 \%$ variations in ecological footprint for the next ten years are because of shocks in public revenue, current public expenditure, development expenditure, total population, economic growth, and energy consumption in Pakistan respectively. These results predict that all exogenous variables contribute to the ecological footprint in Pakistan majorly.

The function of the impulse response is employed to check how a certain variable (particularly dependent variable) responds to modifications introduced to other factors or variables. Based on Cholesky's analysis of impulse response functions can be seen in Fig 5.

Response of EFP to EFP
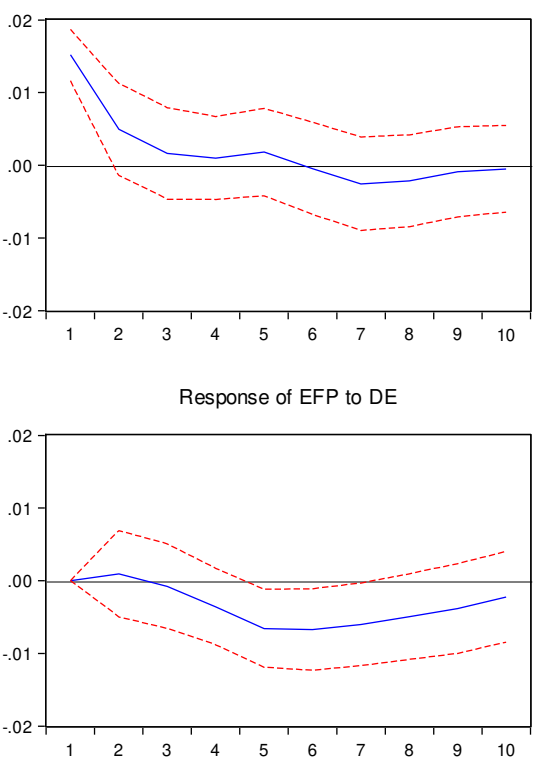

Response of EFP to EU

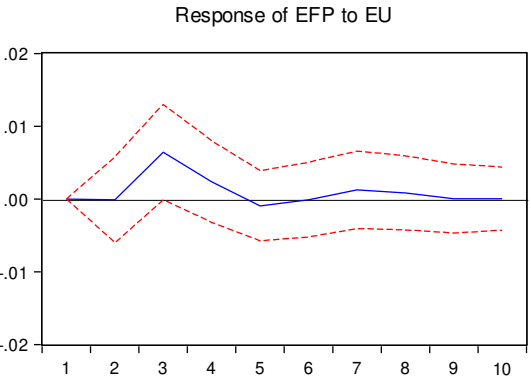
and positive.

Response to Cholesky One S.D. Innov ations \pm 2 S.E.

Response of EFP to TR

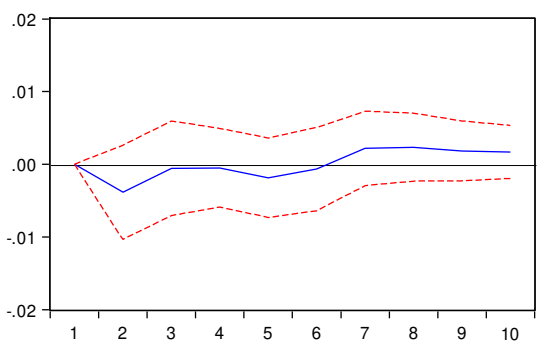

Response of EFP to TP

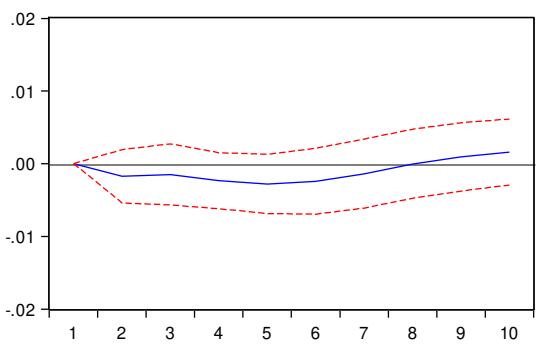

Response of EFP to CE

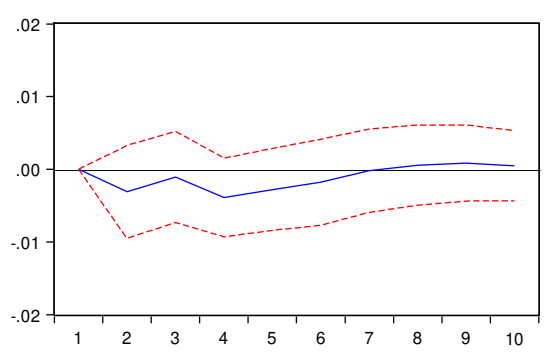

Response of EFP to GDP

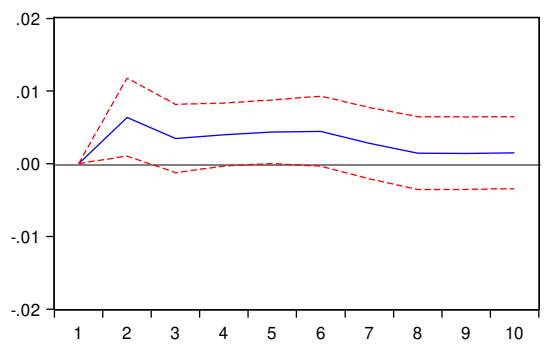

Fig 5: Impulse Response Function.

As shown in Fig 5 it is concluded from the results of the effects of shocks the adjustment path of the variables that the reaction of ecological footprint to independent variables seems significant

\section{Conclusion and Recommendations}

The core objective of this research paper is to explore the short-run and long-run impact of fiscal and some of the socio-economic indicators on the ecological footprint in Pakistan between 1976 and 2018. Different econometric techniques are used to explore this association between fiscal 
513 policy and ecological footprint in Pakistan. Johansen co-integration test (applying trace test as 514 standard) determines that there are six co-integrating factors at 0.05 level of significance. 515 Secondly, the ARDL model is used to explore the short-run and long-run socio-economic and 516 fiscal determinants of ecological footprint for the era of 1976 to 2018 in Pakistan. It is concluded 517 that public development expenditures, the total population of Pakistan, economic growth, and energy consumption are major determinants of ecological footprint with positive dominancy, 519 depicting the increase in their values expands ecological footprint in Pakistan. Similarly, total 520 public tax and non-tax revenue and current public expenditures have a negative relationship with 521 the dependent variables in long run; determining the increase in both of them will reduce the 522 ecological footprint in Pakistan.

523 For policy implications and recommendations, these results focus on adorable and practical fiscal 524 policy significance to achieve environmental targets in Pakistan. It is suggested to increase the 525 share of public current expenditures in the total sphere of public expenditures. Therefore in 526 developing countries like Pakistan, it is necessary to increase public spending in public and social 527 sectors such as health, education, environmental safety, and other important social sectors. This 528 will increase the share of current expenditures by the Government of Pakistan in total public spending, which will reduce the ecological footprint in Pakistan in the long-run.

530 Similarly, an increase in public revenue can cause a decrease in ecological footprint in Pakistan, 531 insisting the policymakers increase the tax net and tax base. Special concentration is required to 532 bring more and more taxpayers into the tax net in Pakistan.

533 Green banking is an environmental strategy to accelerate the capital for clean energy projects to 534 improve environmental quality and to reduce the ecological footprint. However, in Pakistan 535 economic policies to invest in green production along with the decrease in carbon emission is being 536 struggled to design by administration and academics (Ullah et al., 2020). Therefore, more concrete 537 and elaborative efforts are required in this field to achieve environmental targets. So, public 538 investment in green production is suggested.

539 It is also recommended to introduce new economic paradigms and effective domestic and 540 international institutions to achieve sustainable economic development coupled with 541 environmental sustainability. As ecological footprint has the issue of environmental convergence 542 in the whole world. 
543 Concentration to improve renewable energy sources than rely on fossil fuel only is also suggested 544 to decrease ecological footprint in Pakistan and to improve environmental quality. Similarly, along 545 with an increase in investment in the sphere of renewable energy, capital is also required to 546 improve the existing fossil fuels energy plants.

549 Authors' contributions: Samia Zahra: Conceptualization, Methodology, Formal Analysis, 550 Investigation, Writing-Review \& Editing. Muhammad Nouman: Eviews Analysis. Dr. Dilawar Khan: 551 Helped in selection of appropriate Econometric Models.

552 Data Availability: The datasets used and/or analyzed during the current study are available from 553 the corresponding author on reasonable request.

554 Compliance with ethical standards:

555 Ethical Approval: Not Applicable

556 Consent to participate: I am free to contact any of the people involved in the research to seek 557 further clarification and information.

558 Consent to publish: Not applicable.

559 Funding: Not applicable.

560 Competing Interests: The authors declare no potential conflicts of interest concerning the 561 research, authorship, and publication of this article. 
571 Adewuyi, A. O. (2016). Effects of public and private expenditures on environmental pollution: A

572 dynamic heterogeneous panel data analysis. Renewable and Sustainable Energy Reviews, 65, 489-

573506.

574 Alvarado, R., \& Toledo, E. (2017). Environmental degradation and economic growth: evidence

575 for a developing country. Environment, Development and Sustainability, 19(4), 1205-1218.

576 Angelopoulos, K., Economides, G., \& Philippopoulos, A. (2013). First-and second-best 577 allocations under economic and environmental uncertainty. International Tax and Public 578 Finance, 20(3), 360-380.

579 Apergis, N., \& Payne, J. E. (2010). Renewable energy consumption and economic growth: 580 evidence from a panel of OECD countries. Energy policy, 38(1), 656-660.

581 Baabou, W., Grunewald, N., Ouellet-Plamondon, C., Gressot, M., \& Galli, A. (2017). The 582 Ecological Footprint of Mediterranean cities: Awareness creation and policy 583 implications. Environmental Science \& Policy, 69, 94-104.

584 Balcilar, M., Çiftçioğlu, S., \& Güngör, H. (2016). The effects of financial development on 585 Investment in Turkey. The Singapore Economic Review, 61(04), 1650002.

586 Barman, T. R., \& Gupta, M. R. (2010). Public expenditure, environment, and economic 587 growth. Journal of Public Economic Theory, 12(6), 1109-1134.

588 Baumol, W. J., Baumol, W. J., Oates, W. E., Baumol, W. J., Bawa, V. S., Bawa, W. S., \& Bradford, 589 D. F. (1988). The theory of environmental policy. Cambridge university press.

590 Bertinelli, L., Strobl, E., \& Zou, B. (2008). Economic development and environmental quality: A 591 reassessment in light of nature's self-regeneration capacity. Ecological Economics, 66(2-3), 371592378.

593 Bostan, I. (2015). Promotion and Support of the Natural Capital: Research on Ensuring the 594 Financial Resources for the Conservation of Biodiversity (CBD) in the Romanian 595 Space. International Journal of Environmental Research, 9(2). 

OF ENTROPY ON ECONOMIC SYSTEMS. Environmental Engineering \& Management Journal (EEMJ), 15(11).

Bostan, I., Burciu, A., \& Condrea, P. (2010). Trends of the communitarian cohesion policies and advertising for eco-investments. Environmental Engineering \& Management Journal (EEMJ), 9(6).

Breusch, T. (1978). Testing for autocorrelation in dynamic linear models. Journal of Australian Economic Paper, 17(1), 334-555.

Brown, R. L., Durbin, J., \& Evans, J. M. (1975). Techniques for testing the constancy of regression relationships over time. Journal of the Royal Statistical Society: Series B (Methodological), 37(2), 149-163.

Burciu, A., Bostan, I., Condrea, P., \& Grosu, V. (2010). Financing the environmental policies in the communitarian space. Environmental Engineering \& Management Journal (EEMJ), 9(9).

Byrne, M. M. (1997). Is growth a dirty word? Pollution, abatement, and endogenous growth. Journal of Development Economics, 54(2), 261-284.

Chan, Y. T. (2020). Are macroeconomic policies better in curbing air pollution than environmental policies? A DSGE approach with carbon-dependent fiscal and monetary policies. Energy Policy, 141, 111454.

Dickey D, Fuller W (1981) Likelihood ratio statistics for autoregressive time series with a unit root. Econometrica 49(4):1057-1072.

Dongyan, L. (2009). Fiscal and tax policy support for energy efficiency retrofit for existing residential buildings in China's northern heating region. Energy Policy, 37(6), 2113-2118.

Engle, R. F. (1982). Autoregressive conditional heteroscedasticity with estimates of the variance of United Kingdom inflation. Econometrics, 50(4), 987-1008.

Fischer, C., \& Heutel, G. (2013). Environmental macroeconomics: Environmental policy, business cycles, and directed technical change. Annu. Rev. Resour. Econ., 5(1), 197-210. 
622 Fodha, M., \& Zaghdoud, O. (2010). Economic growth and pollutant emissions in Tunisia: an 623 empirical analysis of the environmental Kuznets curve. Energy policy, 38(2), 1150-1156.

624 GNF, 2020 Global Footprint Network (GNF): National Footprint Accounts, Ecological Footprint. 625 Retrieved from http://data.footprintnetwork.org.

626 Godfrey, L. (1978). Testing for Higher Order Serial Correlation in Regression Equations When 627 the Regressors Include Lagged Dependent Variables. Econometrica, 46(6), 1303-10.

628 Granger, C. W. J. \& Newbold, P. (1974). Spurious regressions in econometrics. Journal of 629 Economics, $l(2), 111-120$.

630 Granger, C. W. J. \& Newbold, P. (1974). Spurious regressions in econometrics. Journal of 631 Economics, $l(2), 111-120$.

632 Grossman, G. M., \& Krueger, A. B. (1995). Economic growth and the environment. The quarterly 633 journal of economics, 110(2), 353-377.

634 Halkos, G. E., \& Paizanos, E. A. (2013). The effect of government expenditure on the 635 environment: An empirical investigation. Ecological Economics, 91, 48-56.

636 Halkos, G. E., \& Paizanos, E. A. (2016). The effects of fiscal policy on CO2 emissions: evidence 637 from the USA. Energy Policy, 88, 317-328.

638 Hossain, S. (2012). An econometric analysis for CO 2 emissions, energy consumption, economic 639 growth, foreign trade and urbanization of Japan.

640 Jalil, A., \& Mahmud, S. F. (2009). Environment Kuznets curve for CO2 emissions: a cointegration 641 analysis for China. Energy policy, 37(12), 5167-5172.

642 Janjua PZ, Samad G, Khan N (2014) Climate change and wheat production in Pakistan: an 643 autoregressive distributed lag approach. Wageningen J Life Sci 68:13-19

644 Jarque, C. M., \& Bera, A. K. (1987). Regression Residuals. International Statistical Review/Revue 645 Internationale de Statistique, 55(2), 163-172.

646 Johansen, S. (1988). Statistical analysis of cointegration vectors. Journal of economic dynamics 647 and control, 12(2-3), 231-254. 
648 Johansen, S. (1991). Estimation and hypothesis testing of cointegration vectors in Gaussian vector 649 autoregressive models. Econometrica: journal of Econometric Society, 59(6):1551-1580

650 Johansen, S., \& Juselius, K. (1990). Maximum likelihood estimation and inference on 651 cointegration - with appucations to the demand for money. Oxford Bulletin of Economics and 652 statistics, 52(2), 169-210.

653 John, A., \& Pecchenino, R. (1994). An overlapping generation's model of growth and the 654 environment. The economic journal, 104(427), 1393-1410.

655 Katircioglu, S., \& Katircioglu, S. (2018). Testing the role of fiscal policy in the environmental 656 degradation: the case of Turkey. Environmental Science and Pollution Research, 25(6), 56166575630.

658 Kuo, T. C., Hong, I. H., \& Lin, S. C. (2016). Do carbon taxes work? Analysis of government 659 policies and enterprise strategies in equilibrium. Journal of cleaner production, 139, 337-346.

660 Liu, Y., Han, L., Yin, Z., \& Luo, K. (2017). A competitive carbon emissions scheme with hybrid 661 fiscal incentives: The evidence from a taxi industry. Energy Policy, 102, 414-422.

662 Liu, Y., Han, L., Yin, Z., \& Luo, K. (2017). A competitive carbon emissions scheme with hybrid 663 fiscal incentives: The evidence from a taxi industry. Energy Policy, 102, 414-422.

664 Lopez, R. E., \& Palacios, A. (2010). Have government spending and energy tax policies 665 contributed to make Europe environmentally cleaner? (No. 1667-2016-136345).

666 López, R., \& Palacios, A. (2014). Why has Europe become environmentally cleaner? 667 Decomposing the roles of fiscal, trade and environmental policies. Environmental and Resource 668 Economics, 58(1), 91-108.

669 López, R., Galinato, G. I., \& Islam, A. (2011). Fiscal spending and the environment: theory and 670 empirics. Journal of Environmental Economics and Management, 62(2), 180-198.

671 Martínez-Zarzoso, I. (2011). The log of gravity revisited. Applied Economics, 45(3), 311-327.

672 McAusland, C. (2008). Trade, politics, and the environment: Tailpipe vs. smokestack. Journal of 673 Environmental Economics and Management, 55(1), 52-71. 
674 Mohammed Saud M, A., Guo, P., Haq, I. U., Pan, G., \& Khan, A. (2019). Do government 675 expenditure and financial development impede environmental degradation in Venezuela?. PloS 676 one, 14(1), e0210255.

677 Muhafidin, D. (2020). The Role of Fiscal Policy and Monetary Policy in Environmental 678 Degradation in Indonesia. International Journal of Energy Economics and Policy, 10(3), 504.

679 Naradda Gamage, S. K., Hewa Kuruppuge, R., \& Haq, I. U. (2017). Energy consumption, tourism 680 development, and environmental degradation in Sri Lanka. Energy Sources, Part B: Economics, 681 Planning, and Policy, 12(10), 910-916.

682 Narayan, P. K., \& Narayan, S. (2010). Carbon dioxide emissions and economic growth: Panel data 683 evidence from developing countries. Energy policy, 38(1), 661-666.

684 Oueslati, W. (2002). Environmental policy in an endogenous growth model with human capital 685 and endogenous labor supply. Economic Modelling, 19(3), 487-507.

686 Ozturk, I., \& Al-Mulali, U. (2015). Investigating the validity of the environmental Kuznets curve 687 hypothesis in Cambodia. Ecological Indicators, 57, 324-330.

688 Pesaran, M. H., Shin, Y. \& Smith, R. J. (2001). Bounds testing approaches to the analysis of level 689 relationships. Journal of Applied Economics, 16(3), 289-326.

690 Pohoata, I., Bostan, I., Prelipceanu, G., Drugus, D., Morariu, A., \& Bunget, O. (2014). Equity, 691 intra/inter-generation equalization and profit, in the context of the right to a healthy life and a clean 692 environment. Revista Romana de Bioetica, 12(2).

693 Postula, M., \& Radecka-Moroz, K. (2020). Fiscal policy instruments in environmental 694 protection. Environmental Impact Assessment Review, 84, 106435.

695 Ramsey, J. B. (1969). Tests for specification errors in classical linear least-squares regression 696 analysis. Journal of the Royal Statistical Society: Series B (Methodological), 31(2), 350-371.

697 Sarkodie, S. A. (2020). Environmental performance, biocapacity, carbon \& ecological footprint of 698 nations: Drivers, trends and mitigation options. Science of the Total Environment, 751, 141912. 
699 Shahbaz, M., Sbia, R., Hamdi, H., \& Ozturk, I. (2014). Economic growth, electricity consumption, 700 urbanization and environmental degradation relationship in United Arab Emirates. Ecological 701 Indicators, 45, 622-631.

702 ul Haq, I., Zhu, S., \& Shafiq, M. (2016). Empirical investigation of environmental Kuznets curve 703 for carbon emission in Morocco. Ecological Indicators, 67, 491-496.

704 Vasilev, A. (2019). Optimal fiscal policy with environmental tax and pollution abatement spending 705 in a model with utility-enhancing environmental quality: lessons from Bulgaria. Macroeconomics 706 and Finance in Emerging Market Economies, 12(1), 24-35.

707 White, H. (1980). A Heteroskedasticity-Consistent Covariance Matrix Estimator and a Direct Test 708 for Heteroskedasticity. Econometrica, 48(4), 817-838.

709 Xie, X., \& Wang, Y. (2019). Evaluating the Efficacy of Government Spending on Air Pollution 710 Control: A Case Study from Beijing. International journal of environmental research and public 711 health, 16(1), 45.

712 Yuelan, P., Akbar, M. W., Hafeez, M., Ahmad, M., Zia, Z., \& Ullah, S. (2019). The nexus of fiscal 713 policy instruments and environmental degradation in China. Environmental Science and Pollution $714 \quad$ Research, 26(28), 28919-28932. 


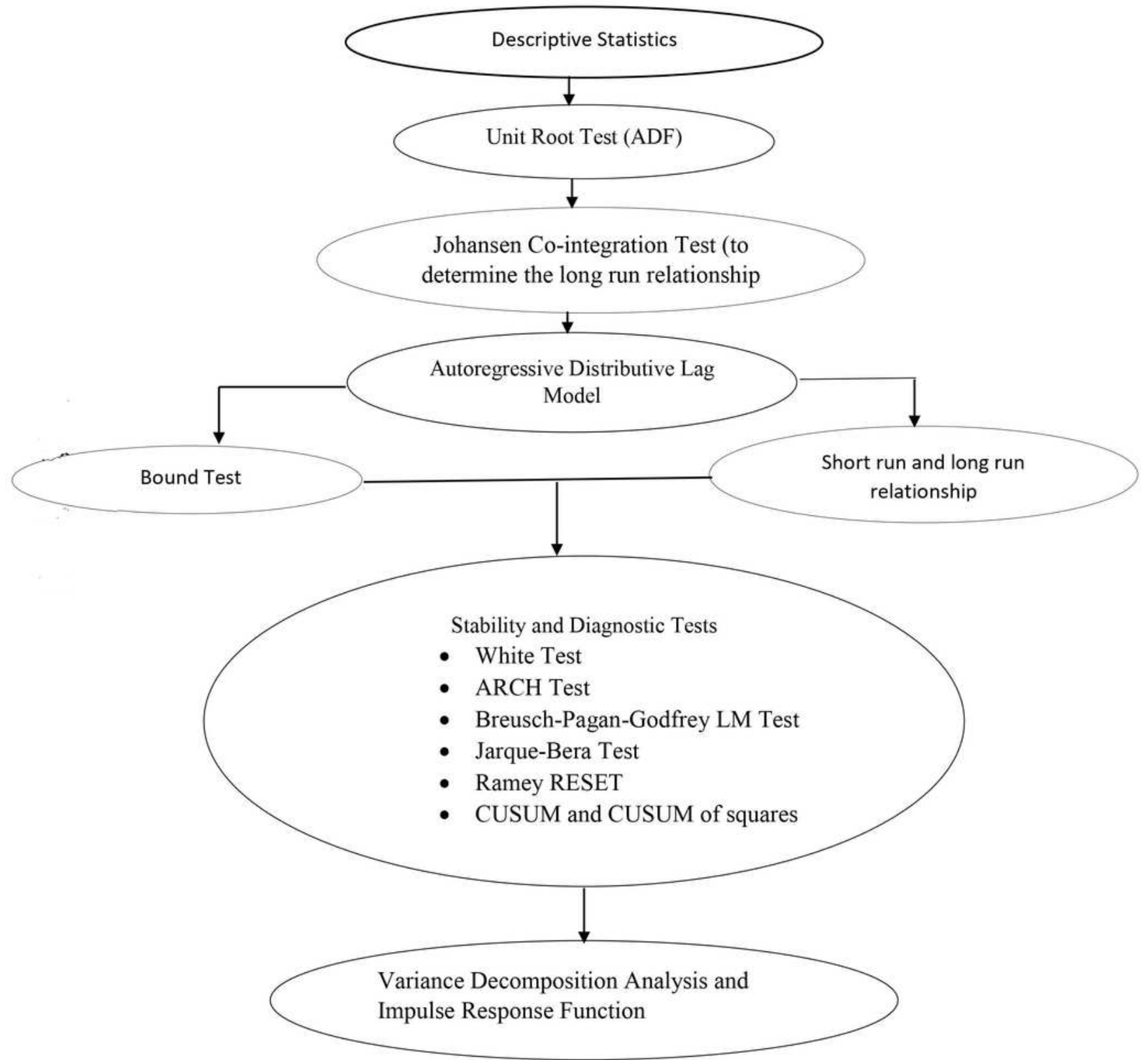

Figure 1

Flowchart of research methodology. 


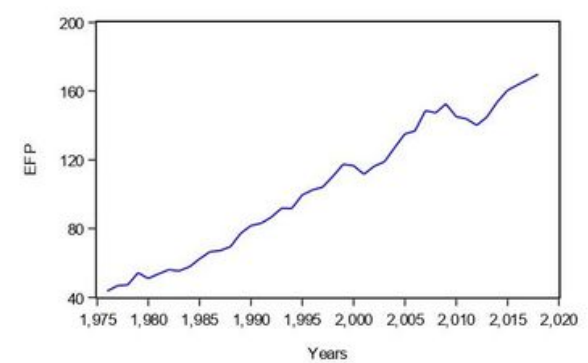

Years
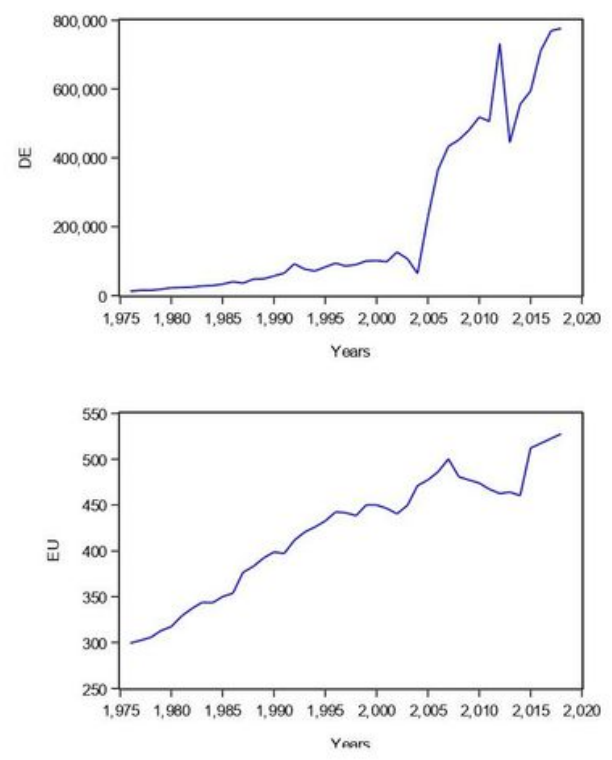
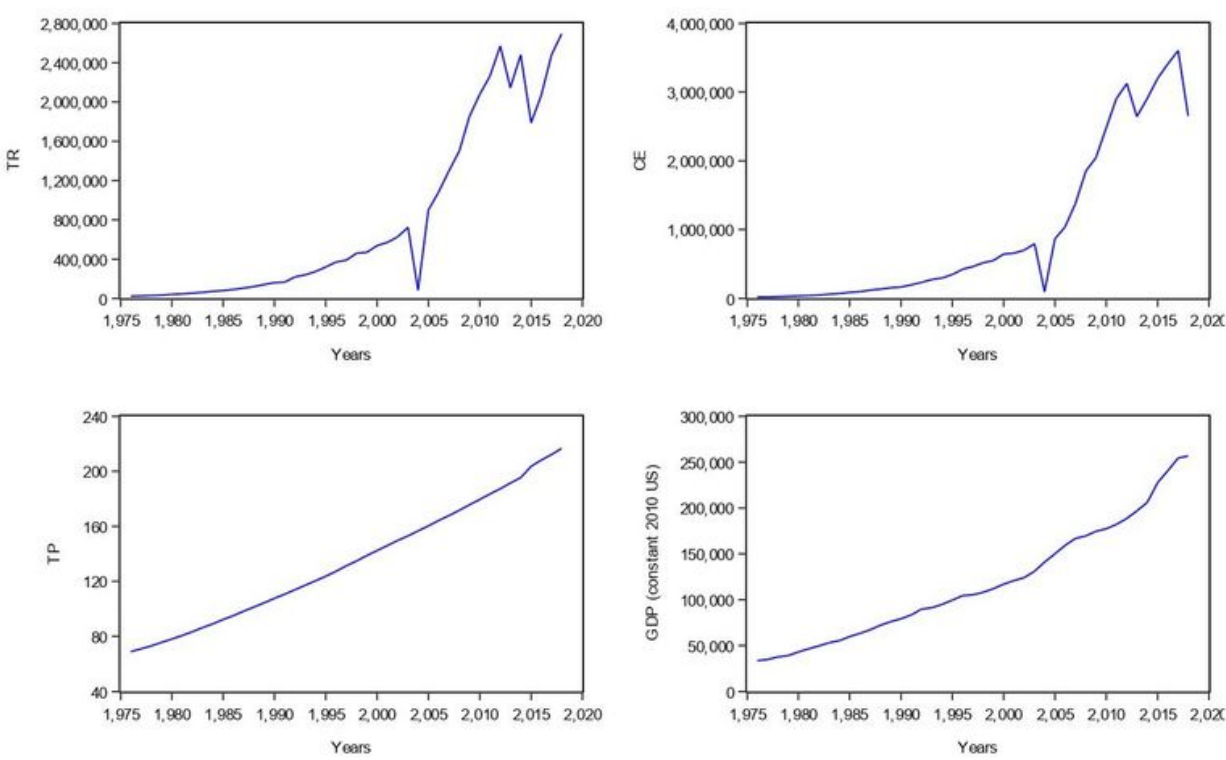

\section{Figure 2}

Periodic trends of ecological footprint and explanatory variables in Pakistan. 


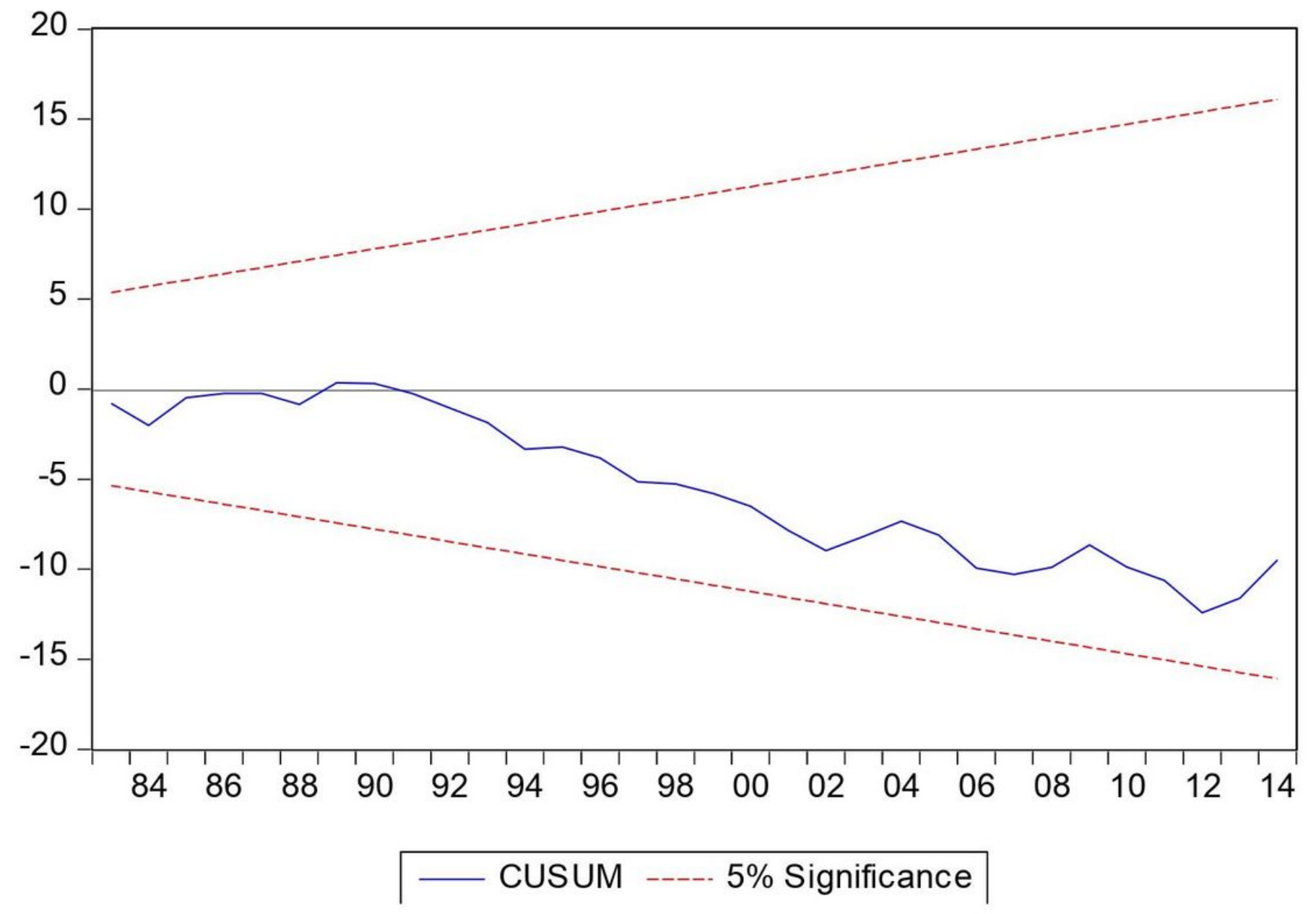

Figure 3

Results of CUSUM test. 


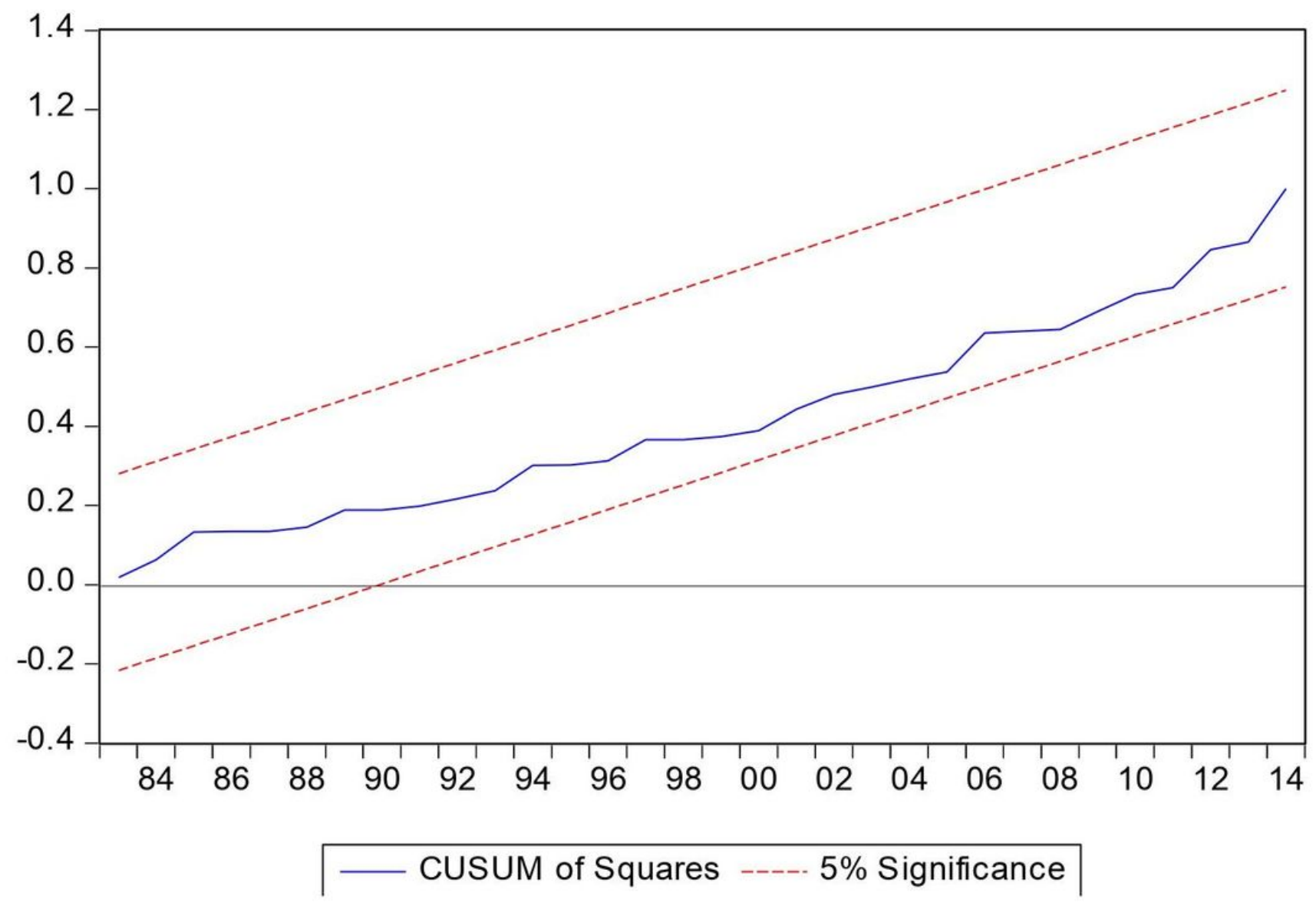

Figure 4

Results CUSUMSQ tests. 
Response of EFP to EFP

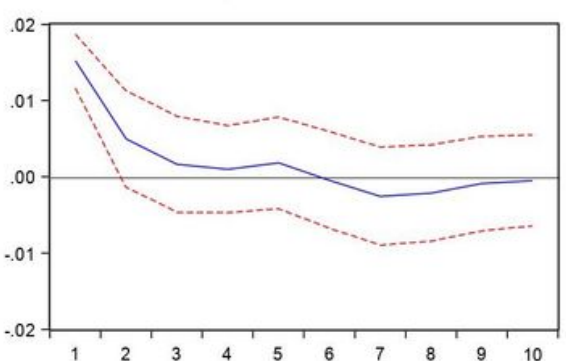

Response of EFP to DE

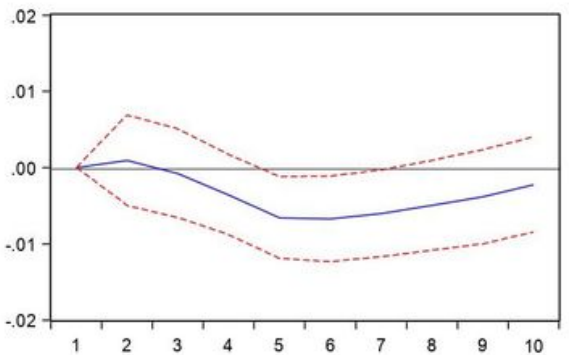

Response of EFP to EU

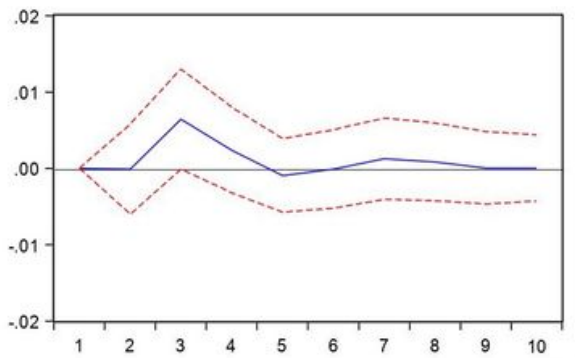

Response of EFP to TR

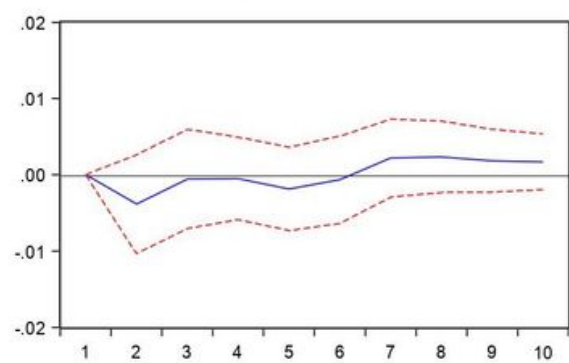

Response of EFP to TP

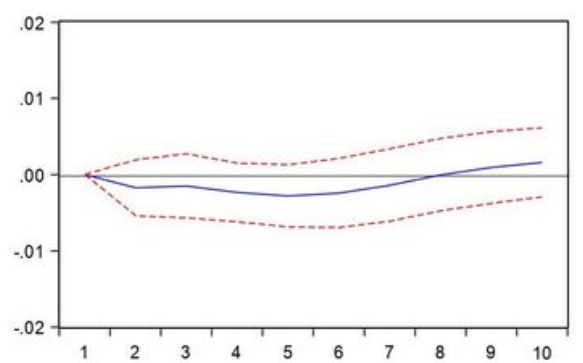

Response of EFP to CE

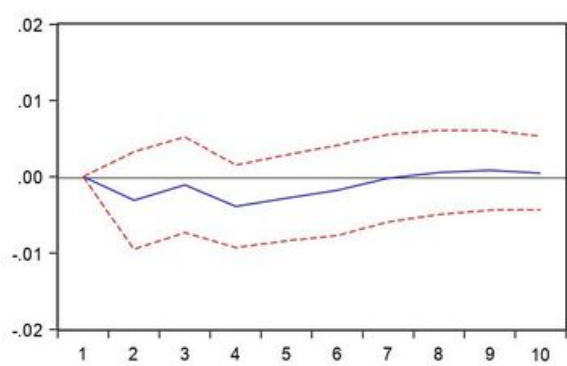

Response of EFP to GDP

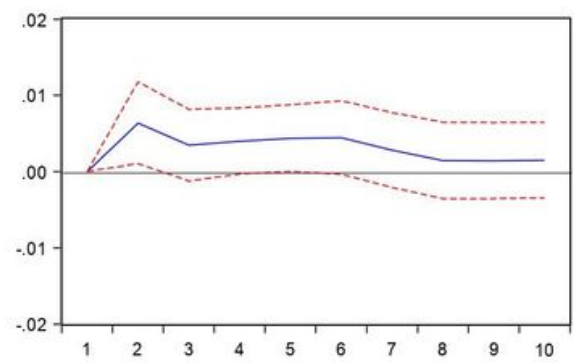

Fig 5: Impulse Response Function.

Figure 5

Impulse Response Function. 